\title{
obituary
}

\section{Samuel A. Goudsmit, 1902-1978}

On 4 December 1978 the world of physics lost one of its most unusual and interesting members when Professor Samuel A. Goudsmit died of a heart attack on the campus of the University of Reno, Nevada. His career was as varied as the times in which he lived; and the changes in science and scientists are accurately mirrored in his actions and his life.

Samuel A. Goudsmit was born in The Hague, The Netherlands, on 11 July 1902; he lived and grew up in a middle class family of merchants. At an early age he showed extraordinary mental agility. He was exceptional in solving puzzles of all kinds. When a young man in high school Goudsmit happened to get a hold of a cheap spectroscope (it presumably belonged to his older sister) and after examining the brilliant spectral colours,Goudsmit was hooked, and spectroscopy and the physics going with it became not only his interest, his hobby and his profession, but a lifelong passion.

Because of his interest first in spectroscopy and later in physics as a whole he started his studies at the University of Amsterdam. After receiving an intermediate degree he went on to obtain his $\mathrm{PhD}$ at the University of Leiden. Although Goudsmit's performance was brilliant (with some notable exceptions when he had no interest in the subject) he was considered somewhat of a failure by his family. Physics at that time was a calling, not a profession; with the certainty that there would be no jobs after completing the degree, it was reasonable that Goudsmit's family had a difficult time understanding his devotion to physics. In spite of his unquestioned early successes he was considered as a bit of a misfit.

At the university Goudsmit did well in physics he did exceptionally well. He was only 19 years old when he pointed out in a paper, (Naturwiss 9, 995, 1921), that the Sommerfeld formula for $\mathrm{x}$-ray doublets was equally valid for alkali doublets. The knowledge, but perhaps even more, the scientific maturity necessary for that observation is highly unusual for a beginning student.

In Leiden, Goudsmit came under the spellbinding influence of Ehrenfest. Ehrenfest was impressed by Goudsmit's talent and interest. The combination of Ehrenfest's insistence on precision and clarity and Goudsmit's natural flair for physics led to Goudsmit's surprisingly rapid development as a scientist. It is therefore understandable that when

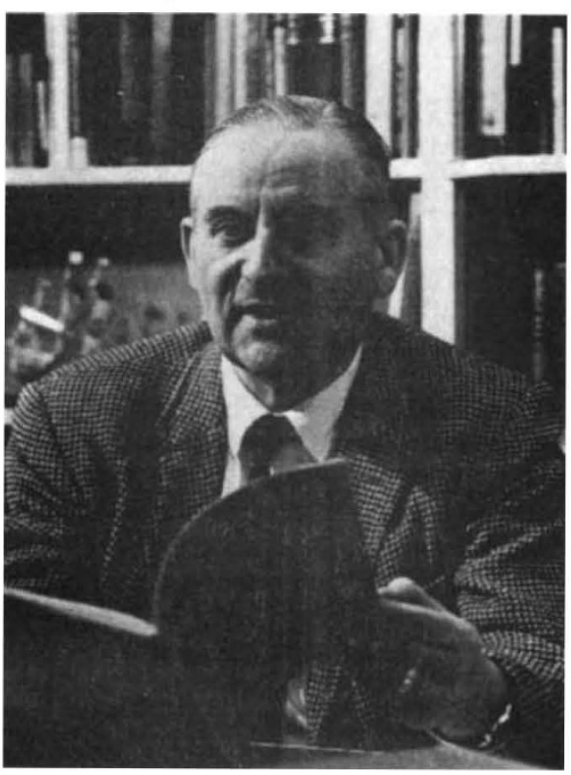

longer in the center of interest. Although Goudsmit later worked in a number of different areas in physics, he never again felt as attuned and in control of a field, as he did in atomic spectroscopy. Although enormously talented Goudsmit often had the feeling that he did not possess enough intellectual technology to function effectively in physics. He had never been terribly interested in mathematics. (He used to say very frequently that he could only understand 2 by 2 matrices and nothing more. This is probably not true, but if it were he certainly made the absolute maximal use of the mathematics he controlled.) Goudsmit often expressed concern about his lack of mathematical ability. He felt that in order to advance in experimental physics a rather detailed understanding of accelerating machinery was essential - that knowledge he did not have either. This made it difficult to choose an effective new research area. There can be little doubt that the dramatic ending of Ehrenfest's life and the calamitous European political situation of the 1930's had a profound effect on Goudsmit. This affected everybody and in particular a sensitive person like Goudsmit. His scientific productivity obviously suffered and this in turn added to his general dissatisfaction with himself and with the world.

It cannot come as a surprise that when the Second World War broke out Goudsmit felt honour bound to take as active a part as possible. He first joined the MIT radiation laboratory and did some work on radar. Later he became the Chief Scientific Officer of the Alsos Project. This was a remarkable scientific intelligence mission; its purpose was to find the extent and status of German atomic weapons research. The results of his mission are written up in a book entitled Alsos (Sigma Books, London 1947) which unfortunately is out of print. It describes the mood and the atmosphere of wartime research in Germany. It is also intensely personal and written with great sensitivity - even pathos as when Goudsmit learned that his parents had been deported to an extermination camp. Only those who have suffered the trauma of tragedy and guilt which accompanies the total distruction of a family will fully appreciate the depression that is produced and only they will understand the extraordinarily painful struggle needed to keep going and in fact start anew.

After a short sojourn at Northwestern 
University, 1946-1948, Goudsmit joined the Brookhaven National Laboratory in 1948. His interest and devotion to physics was as intense as ever. From 1952 to 1960 he was Chairman of the Brookhaven Physics Department; but equally important was his influence as Managing Editor of the Physical Review. He initiated the first letters journal, Physical Review Letters, still the most prestigous letter journal in physics.

Goudsmit received many honours, most of which were in connection with the discovery of spin. As expected he shared many of the honours with the codiscoverer of spin, George Uhlenbeck. They received the Research Corporation Science Award (1954), the Max Planck Medal of the German Physical Society (1965), the Karl T. Compton Award for Distinguished Statesmanship in Science, American Institute of Physics (1974) and the National Medal of Science (1977). There was also a commemorative meeting about spin and its discovery at the American Physical Society Annual Meeting in January 1976. Goudsmit and Uhlenbeck got their PhD degrees on the same day, 6 July, 1927. To express the appreciation and admiration of the Dutch scientists a special symposium was held to honour the 50th anniversary of their PhD degrees on 6 July 1977. It was a two day symposium with two highlights: the public highlight occurred when Goudsmit and Uhlenbeck received from the Dutch Government a very high decoration in recognition of their great accomplishments. This was not only a signal honour but a diplomatic feat as well, for such decorations can only be granted to Dutch citizens and Goudsmit and Uhlenbeck although born in Holland, were both naturalized American citizens.

But probably the more impressive and certainly the more touching celebration came when I walked with Goudsmit to the room where 50 years before he had taken his $\mathrm{PhD}$ examination. In that old room at the University of Leiden it is a tradition that after passing an examination the students write their names on a wall giving the date and type of examination. Goudsmit had bought a "magic marker" for the occasion; together we walked into the room where he had taken the examination (cver the mild objection of the doorman). On the wall were hundreds of signatures. After some searching we found Goudsmit's signature for the right exam at the right time. Right above it Goudsmit wrote his signature with the black magic marker and added "Golden Jubilee of the PhD, July 6, 1977'”. After that we very quietly walked back. It was very clear to Goudsmit this was a significant and important event.

With the passing of Samuel Goudsmit the world of physics, indeed the whole world has lost a person of great sensitivity, understanding and talent. He was a man of fanatical honesty who detested circumlocution and vagueness. He was the exact opposite of pompous. His standards in physics and in life were extraordinarily high. He made corresponding demands on those around him - on his colleagues, on physics, and most certainly upon himself. That does not make for a terribly easy life, it does not make for a uniformly happy life, but it does mean that one can say with honesty and conviction - it mattered to the world that Samuel Goudsmit lived.

\section{Max Dresden}

\section{R.N. Pryor}

ROBERT NELSON PRYOR died of a heart attack in London on 14 July 1979, a few days short of his 58th birthday. He was at the peak of his powers and authority as a leading figure in the mining world.

Born in India while his father, a prominent mining engineer, was working in the Kolar Gold Fields, he was educated at Oundle and entered the Royal School of Mines, Imperial College, in 1939. After a year in which he played rugby for the RSM and rowed in the college first VIII, he joined the Royal Engineers and served in India and then with the Chindits in Burma. $\mathrm{He}$ finished the war with the rank of Captain, married the daughter of a New Zealand mining engineer, and returned to the College to obtain a first class honours degree in mining engineering in 1948.

His early career had a curious six-yearly cycle. Six years in the army and, when on graduation he went to Rio Tinto Mines in Spain, he spent six years in junior management before being made Chief Mining Engineer - a position which he occupied for six years. He then returned to the London office of Rio Tinto Zinc from where, for six years, he examined new mining projects including potash, leadzinc, copper, nickel and pyrite in various parts of the world. In 1966 he was invited by the Spanish directors to become General Projects Manager of Rio Tinto Patiño, and in this post he supervised the launching of Cerro Colorado, the largest gold and copper mine in West Europe, and started construction of a new copper smelter and refinery at Huelva. His long and important contributions to Spanish mining did not go unrecognised, for in 1977 he became the first foreigner to receive honorary membership of the Asociacion de Ingenieros de Minas de España.

In 1968 he was appointed Professor of Mining at Imperial College and brought back to his old school a wealth of experience in modern mining practice and management. As a teacher, his particular interests were in mineral production management, the design of large open-cast operations and in countering the environmental effects of mining past and future. He was much in demand as a consultant and, as his reputation grew, he became increasingly involved in recalcitrant problems, world-wide, as both technical adviser and arbiter. This heightened authority and experience was used to the benefit of his students - both undergraduate and postgraduate - and of his staff, many of whom were involved with him in the important, topical problems on which he was engaged.

In 1974 he became Head of the Department of Mineral Resources Engineering and, about the same time, began to assume the influence in professional engineering circles that culminated in his presidency of the Institution of Mining and Metallurgy and membership of the Executive Committee of the Council of Engineering Institutions. He did not spare himself, contributing in full to both organizations and serving as chairman and member of a large number of committees. Because he firmly believed that the engineering professions must come closer together, he was also an active Fellow of the Institution of Civil Engineers. He exemplified his conviction by organizing the Tunnelling '76 and Tunnelling ' 79 International Symposia highly successful meetings which involved all three Institutions.

With his Presidential Address to the IMM, "Towards a Minerals Policy", delivered in June 1978, Bob Pryor embarked on what was to be his final project - to persuade the professions, industry and government of the need to take active, positive steps to ensure our vital mineral supplies. He followed this up with an informal meeting between government officials and representative mining and metallurgical experts in March 1979 , and was one of the prime movers in arranging the National Symposium on the Availability of Strategic Minerals to be held in November of this year. His final contribution was an address entitled "Ensuring Access to Vital Supplies for Britain", which I read to the Parliamentary and Scientific Committee a few days after his death.

There was no badinage, no easy smalltalk and certainly no flattery; but to his friends and those who enjoyed his confidence, he was the best of companions - warm and frank, interested and sympathetic, forthcoming and always sincere. Although his own standards were so high, he was in no way smug. He neither expected nor wanted others to share his views except by conviction. He was stubborn but open to reason. He was firm but generous. He had pride, but no conceit and, indeed, he was unduly diffident in some respects. He was humane and tolerant - up to a point - but he could not tolerate dishonesty. If, to these characteristics, you add intelligence, industry, an acute critical faculty, determination and a deep sense of responsibility, you have leadership. If you add courage and absolute integrity, you have a model for a complete professional engineer.

He is survived by his wife Patricia, three sons and daughter. M.G. Fleming 